\title{
Fermented Coconut Dregs Quality and Their Effects on the Performance of Broiler Chickens
}

\author{
Hafsah*, H. B. Damry, U. Hatta, \& B. Sundu \\ Animal Husbandry Department, Faculty of Animal Husbandry and Fisheries, Universitas Tadulako, \\ Palu, Central Sulawesi, Indonesia \\ *Corresponding author: email: hafsah62@yahoo.com \\ (Received 23-12-2019; 09-04-2020; Accepted 21-04-2020)
}

\begin{abstract}
This study was conducted to determine the effects of the fermentation duration of coconut dregs (CD) by Saccharomyces cerevisiae and the addition of ammonium sulfate on the growth performance, feed digestibility, carcass, and digestive organ developments. A finely ground CD was autoclaved at $20 \mathrm{psi}$ for 20 minutes and added distilled water to meet $80 \%$ moisture content. The autoclaved substrate was added with different concentrations of ammonium sulfate and fermented with Saccharomyces cerevisiae to produce Saccharomyces cerevisiae-fermented CD. A total of 192 day-oldunsexed Cobb broiler chicks were used and kept for 6 weeks. The birds were fed experimental diets ad-libitum. The experimental diets were produced by two durations of fermentation ( 5 days and 7 days) and three levels of ammonium sulfate $(0 \%, 0.2 \%$, and $0.4 \%)$ in 4 replicates. The experimental diets were offered ad-libitum and water were available at all times. Fermentation decreased lipid and crude fiber content of $C D$ and the addition of ammonium sulfate increased protein content and amino acid concentration of CD. The bodyweight gain of birds increased when the CD was fermented for 5 days and with the addition of $0.2 \%$ ammonium sulfate. Dry matter digestibility and protein digestibility were improved when $C D$ was added with $0.2 \%$ ammonium sulfate. In conclusion, fermenting $C D$ for 5 days increased body weight gain and the addition of $0.2 \%$ ammonium sulfate improved the feeding value of the diet and growth of birds.
\end{abstract}

Keywords: ammonium sulfate; coconut dregs; fermentation period; poultry; Saccharomyces cerevisiae

\section{INTRODUCTION}

Application of fermentation technology in poultry nutrition is widely established for the improvement of the feed quality. Mechanisms behind the improved feeding value of diets were through several modus operandi. Production of simple substances, bioconversion of inorganic minerals into an organic fraction (Sugiharto \& Ranjitkar, 2019; Sukaryana et al., 2010), elimination of toxic compounds (Nyamete et al., 2016), and improved aroma (Sukaryana et al., 2010; Saunshia et al., 2018) were some of the fermentation benefits when fermentation technologies were applied in feed technology. Among the existed fermentation technologies, a solid-state fermentation has been widely used due to its practicality, environmentally friendly, and relatively low cost (Kapilan, 2015; Abhiney et al., 2012). The utilization of agricultural by-products as a solid substrate provides nutrient and physical support for the growth of microorganisms (Kumar \& Kanwar, 2012).

Coconut dreg (CD) is one of the agricultural waste products that are abundantly available in Indonesia. Of 60.8 million tons of world coconut production, Indonesia produced $31.2 \%$ of global coconut, being the world's largest producer in 2017 (FAO, 2017). Since this waste product was of low quality with $36.7 \%$ crude fiber and $5.7 \%$ protein (Sundu et al., 2019), it uses in animal feed, particularly in poultry diet, is strictly limited or even scarce. An effort to increase its quality through solid-state fermentation has been made by Sundu et al. (2019) with promising results. A solid-state fermentation technology requires fungi to utilize chemical compounds in the substrate and convert them into the more digestible nutrients.

The potential of this technology to bio convert inorganic minerals that might be toxic for monogastric animals into digestible organic substances has been reported by Mozin et al. (2019) and Sundu et al. (2019). Saccharomyces cerevisiae and Aspergillus niger were the two fungi used to bio convert poisonous sodium selenite into the more absorbable minerals (Mozin et al., 2019) when rice bran was used as a solid substrate. The logic was based on the fact that microorganisms in the gut of ruminants could utilize poisonous non-protein nitrogen to generate microbial proteins that are beneficial for the host. Accordingly, when nitrogen and sulfur were supplied in the form of ammonium sulfate prior to fermentation, the microbes could convert these two minerals 
into amino acids, particularly sulfur-containing amino acids such as methionine and cysteine, in the substrate. This hypothesis becomes the novelty of the study and differentiates this study from previous studies reported in the database.

Ammonium sulfate is an inorganic mineral containing nitrogen and sulfur in high concentrations, being $21 \%$ and $24 \%$, respectively. Nitrogen is the main component of protein, while sulfur is the raw material for the synthesis of amino acids containing sulfur, methionine, and cysteine. Since microorganisms possess the capability to convert nitrogen into protein microbes, it is possible that fermenting coconut dregs as a low protein substrate with the addition of minerals containing nitrogen and sulfur could increase the amino acid concentration and thus improve the feeding value of the diet. Improving the quality of coconut dregs in the aspect of amino acid concentration is the main target and being the novelty of this study. Therefore, this study was conducted to determine the influence of ammonium sulfate levels and the fermentation duration of $\mathrm{CD}$ on the quality of $\mathrm{CD}$, growth performance, carcass percentage, and the development of the digestive organ in broiler chickens.

\section{MATERIALS AND METHODS}

\section{Fermentation Procedure}

Coconut dregs were purchased from the traditional local market and oven-dried at $50^{\circ} \mathrm{C}$ for four consecutive days. The use of low temperatures in oven-drying was aimed at protecting the protein from Maillard reaction that could downgrade its quality. The oven-dried CD was finely ground to a size of $1-2 \mathrm{~mm}$. The fine CD was used as a solid substrate for fermentation. The bakery yeast Saccharomyces cerevisiae $\left(\right.$ Fermipan $^{\circledR}$ ) was purchased from the local supermarket. The fermentation process was carried out using a method of Jacob \& Prema (2006). The finely dried CD was then autoclaved for 20 minutes at 20 psi and then cooled to room temperature. The cooled substrates were added ammonium sulfate with concentrations of $0 \%, 0.2 \%$, and $0.4 \%$ coconut dregs dry matter prior to the inoculation with 346 $\mathrm{CFU} / \mathrm{g}$ of Saccharomyces cerevisiae or equivalent to $0.1 \%$. Total yeast was measured by using a culture method for the total viable count (Nissen et al., 2003). The substrates and ammonium sulfate were thoroughly mixed. The addition of sterile distilled water into the mixture was conducted to meet an $80 \%$ moisture content. The mixtures were put in 2-kg transparent plastic bags and aerobically incubated. The fermentation was terminated on days 5 and 7 . Also, the fermented substrate was collected and oven-dried at $50^{\circ} \mathrm{C}$ for 48 hours. The fermented substrates were subject to the analysis of proximate (AOAC, 1990), bulk density, and water holding capacity (Kyriazakis \& Emmans, 1995).

\section{Experimental Diets}

This study was designed with a $2 \times 3$ factorial arrangement of treatments with two different durations of fermentation ( 5 and 7 days as used by Mozin et al., 2019) and three different levels of ammonium sulfate $(0 \%, 0.2 \%$, and $0.4 \%)$. All feed ingredients used were obtained from a local poultry shop. Full fat soybean was roasted for 5 minutes with a temperature of $100^{\circ} \mathrm{C}$ to minimize the negative effect of trypsin inhibitor. A hammer mill with a screen size of $4.0 \mathrm{~mm}$ was used to grind the corn and roasted full fat soybean. Basal diets (Table 1) were formulated to meet the major nutrients requirements as recommended by NRC (1994) by using UFFF software. Experimental diets mixed by using a cement mixer were: 1 ) was Basal diet $+0.5 \%$ CD fermented for 5 days with $0 \%$ ammonium sulfate addition, 2) was Basal diet $+0.5 \%$ CD fermented for 5 days with $0.2 \%$ ammonium sulfate addition, 3) was Basal diet $+0.5 \%$ CD fermented for 5 days with $0.4 \%$ ammonium sulfate addition, 4) was Basal diet $+0.5 \%$ CD fermented for 7 days with $0 \%$ ammonium sulfate addition, 5) was Basal diet $+0.5 \%$ CD fermented for 7 days with $0.2 \%$ ammonium sulfate addition, and 6) was Basal diet $+0.5 \%$ CD fermented for 7 days with $0.4 \%$ ammonium sulfate addition.

\section{Birds and Cage}

The experimental protocol was presented and approved by the Animal Ethics Committee of the Faculty of Animal Science and Fisheries, Tadulako University, Palu, Indonesia. A total of 192-day old unsexed Cobb broiler chicks were used in this study. The chicks were kept in 6 electrically heated brooder pens for seven days. The spread of New Castle Diseases was controlled by vaccinating the birds on day 3 using Vaksimune ${ }^{\circledR} \mathrm{ND}$ B1. The chicks were then transferred into 20 pens on day 7 and kept the chicks from day 7 to 42 . The broilers were fed the experimental diets ad-libitum and water was available throughout the study, also data collection was

Table 1. Experimental basal diet

\begin{tabular}{lcc}
\hline \multirow{2}{*}{ Ingredients } & \multicolumn{2}{c}{ Quantity (\%) } \\
\cline { 2 - 3 } & Starter diet & Grower diet \\
\hline Full fat soybean meal & 25.0 & 24.5 \\
Corn & 50.0 & 50.4 \\
Fish meal & 13.3 & 11.0 \\
Rice bran & 10.0 & 13.4 \\
Dicalcium phosphate & 0.80 & 1.10 \\
Methionine & 0.20 & 0.10 \\
Lysine & 0.20 & 0.10 \\
Salt & 0.20 & 0.20 \\
Mineral and vitamin mix & 0.30 & 0.20 \\
Calculated nutrients & & \\
Crude protein & 23.08 & 21.19 \\
Metabolizable energy & 3141 & 3154 \\
(kcal/kg) & & \\
Methionine & 0.66 & 0.51 \\
Lysine & 1.49 & 1.28 \\
Selenium & 0.26 & 0.23 \\
Calcium & 1.70 & 0.94 \\
Phosphorus & 0.71 & 0.66 \\
\hline
\end{tabular}


started from day 7. A plastic feeder and drinker were allocated inside each pen. The drinkers and pens were routinely cleaned.

\section{Chemical and Physical Analysis}

Representatives of fermented CD, feed, and excreta were sampled for determination of dry matter, protein, lipid, crude fiber, and ash using a standard method (AOAC, 1990). All samples were ground to pass through a screen size of $0.5 \mathrm{~mm}$. Analysis of amino acids was based on the procedure used by Sundu et al., 2008. A method of Kyriazakis and Emmans (1995) was adopted to measure the bulk density of the CD. The measurement units are stated in $\mathrm{g} / \mathrm{cm}^{3}$. Water holding capacity (WHC) was measured based on the method of Kyriazakis \& Emmans (1995). One g oven-dried CD was placed in a $15 \mathrm{~mL}$ tube and was soaked with distilled water for one day. The soaked samples were centrifuged at $6000 \mathrm{G}$ for 15 minutes. After centrifugation, the liquid was decanted and the solid residue was freshly weighed and oven-dried at $50^{\circ} \mathrm{C}$ for 48 hours. The dried samples were weighed and calculated for WHC, and the WHC was expressed as $\mathrm{g}$ water/g CD. All the analysis was done in duplicate.

\section{Digestibility Study}

On day 35, two broilers from each experimental cage were randomly taken and put them in 24 metabolic pens for measurements of parameters of digestibility for a week. The birds were continuously offered the experimental diets for 7 days. To collect the fecal discharges, a plastic tray matching the size of each metabolic cage was individually placed underneath the cage. The collection of feces was carried out from days 38 to 41 from $07.00 \mathrm{am}$. The feces from each cage were individually weighed after discarding any feed particles, feathers, and the other contaminations by hand-picking. The uncontaminated feces were oven-dried at $50^{\circ} \mathrm{C}$ for 3 days to measure the moisture content. The dried feces from each experimental cage were pooled and ground. The ground samples were analyzed for proximate fractions. The measurements of feed digestibility were based on the total fecal collection method (Kong \& Adeola, 2014).

\section{Carcass and Digestive Organs Dimensions}

At the end of the study, all experimental broilers were sacrificed by cervical dislocation. The length of duodenum, jejunum, ileum, and the weight of the empty gizzard were individually measured. The dimensions of the digestive tract and organs were expressed as $\mathrm{cm} /$ $\mathrm{kg}$ BW for the length of the small intestine and $\mathrm{g} / \mathrm{kg}$ BW for gizzard. Removals of feathers, shank, neck, digestive tract, and organs were conducted to measure carcass, breast, and abdominal fat percentages (Jensen, 1984).

\section{Statistical Analysis}

The study used a completely randomized factorial design with two different durations of fermentation and three different concentrations of ammonium sulfate. Data on nutrients profile due to fermentation and the addition of ammonium sulfate were descriptively analyzed while body weight gain, feed intake, FCR, carcass, abdominal fat, digestibility, and relative weight of digestive organs were subject to the analysis of variance to determine the two main effects and their interaction effects on the parameters measured (Seltman, 2018). Significant effects detected by analysis of variance were further tested by least significant difference (LSD) test using a Minitab Statistical Program.

\section{RESULTS}

Data on nutrient profiles, bulk density, and water holding capacity of Saccharomyces cerevisiae-fermented CD are presented in Tables 2 and 3. Coconut dregs had $31.57 \%$ lipid content. Fermentation of CD without the addition of ammonium sulfate decreased lipid contents between $21.6 \%$ and $27.2 \%$. The addition of ammonium sulfate further decreased lipid concentrations about $44.2 \%$ to $50.4 \%$. Crude fiber of CD decreased, whereas crude protein of CD increased due to fermentation. Physical properties such as bulk density and water holding capacity were improved due to the changes in nutritional concentration of fermented CD.

Amino acid concentrations increased as a result of fermentation. The addition of ammonium sulfate in the CD prior to fermentation expectedly increased amino

Table 2. Nutrients content, bulk density, and water holding capacity of coconut dregs or fermented coconut dregs

\begin{tabular}{|c|c|c|c|c|c|c|c|}
\hline \multirow{3}{*}{ Nutrients } & \multirow{3}{*}{$\begin{array}{l}\text { Coconut } \\
\text { dregs }\end{array}$} & \multicolumn{6}{|c|}{ Treatments } \\
\hline & & \multicolumn{2}{|c|}{$\mathrm{FCD}+0 \% \mathrm{AS}$} & \multicolumn{2}{|c|}{$\mathrm{FCD}+0.2 \% \mathrm{AS}$} & \multicolumn{2}{|c|}{$\mathrm{FCD}+0.4 \% \mathrm{AS}$} \\
\hline & & 5 days & 7 days & 5 days & 7 days & 5 Days & 7 Days \\
\hline Lipid (\%) & 31.57 & 24.76 & 22.96 & 15.64 & 17.59 & 18.67 & 17.69 \\
\hline Crude protein (\%) & 6.19 & 7.71 & 8.54 & 7.26 & 10.13 & 11.02 & 7.58 \\
\hline Crude fiber (\%) & 33.96 & 18.52 & 25.58 & 29.26 & 28.71 & 26.55 & 31.69 \\
\hline Ash (\%) & 3.60 & 2.83 & 5.21 & 2.2 & 1.63 & 2.14 & 1.22 \\
\hline Moisture (\%) & 6.51 & 5.82 & 6.35 & 7.00 & 8.64 & 8.52 & 8.21 \\
\hline Bulk density (g substrate/ $\mathrm{cm}^{3}$ ) & 0.222 & 0.250 & 0.270 & 0.251 & 0.274 & 0.273 & 0.272 \\
\hline WHC (g water/g substrate) & 5.75 & 5.08 & 4.13 & 4.37 & 4.49 & 4.40 & 4.39 \\
\hline
\end{tabular}

Note: $\mathrm{FCD}=$ Fermented coconut dregs; $\mathrm{AS}=$ Ammonium sulfate; $\mathrm{WHC}=$ Water holding capacity. 
acids containing sulfur, cysteine, and methionine, from undetected concentration (12 mg/kg for methionine and $161 \mathrm{mg} / \mathrm{kg}$ for cysteine) to detectable concentrations.

Growth performance, carcass percentage, and abdominal fat are presented in Table 4. The effect of duration of fermentation on body weight gain was statistically significant $(p<0.05)$ in which fermenting CD for 5 days produced a better body weight gain. The addition of $0.2 \%$ ammonium sulfate in the medium increased body weight gain and FCR. Interaction between the du- ration of fermentation and levels of ammonium sulfate did not significantly affect all parameters.

Data on feed digestibility, the relative length and weight of digestive tracts and organs of broiler chickens are presented in Table 5. Duration of fermentation did not produce any significant difference on digestibility of dry matter, protein, relative weight of gizzard, and relative length of the small intestine. Dry matter and protein digestibility were improved due to the addition of $0.2 \%$ ammonium sulfate in the CD before fermentation.

Table 3. Amino acids profile of coconut dregs and fermented coconut dregs (mg/kg)

\begin{tabular}{|c|c|c|c|c|c|c|c|}
\hline \multirow{3}{*}{ Amino acids } & \multirow{3}{*}{$\begin{array}{c}\text { Coconut } \\
\text { dregs }\end{array}$} & \multicolumn{6}{|c|}{ Treatments } \\
\hline & & \multicolumn{2}{|c|}{$\mathrm{FCD}+0 \% \mathrm{AS}$} & \multicolumn{2}{|c|}{$\mathrm{FCD}+0.2 \% \mathrm{AS}$} & \multicolumn{2}{|c|}{$\mathrm{FCD}+0.4 \% \mathrm{AS}$} \\
\hline & & 5 days & 7 days & 5 days & 7 days & 5 days & 7 days \\
\hline Serine & 1229 & 1869 & 3686 & 2747 & 5202 & 2695 & 2655 \\
\hline Phenylalanine & 869 & 1266 & 2677 & 1682 & 3645 & 1962 & 1668 \\
\hline Isoleucine & 738 & 1410 & 2742 & 1974 & 2783 & 2008 & 1690 \\
\hline Valine & 1121 & 1958 & 3766 & 2799 & 4018 & 2892 & 2706 \\
\hline Alanine & 1202 & 2167 & 4371 & 3302 & 3892 & 3100 & 2821 \\
\hline Arginine & 1933 & 2181 & 4069 & 3106 & 5551 & 3489 & 2745 \\
\hline Glycine & 1011 & 1665 & 3396 & 2447 & 4296 & 2347 & 2299 \\
\hline Lysine & 1102 & 2282 & 4111 & 3738 & 3600 & 3482 & 3160 \\
\hline Leucine & 1327 & 2359 & 4416 & 3072 & 4443 & 3184 & 2708 \\
\hline Tyrosine & 485 & 717 & 1548 & 1125 & 2441 & 1219 & 1119 \\
\hline Threonine & 982 & 1720 & 3712 & 2598 & 4751 & 2742 & 2759 \\
\hline Histidine & 324 & 609 & 1198 & 908 & 1877 & 918 & 896 \\
\hline Cysteine & UD & UD & UD & UD & 302 & UD & 183 \\
\hline Methionine & UD & UD & UD & 278 & UD & 210 & UD \\
\hline Tryptophan & 488 & 667 & 805 & 815 & 861 & 849 & 854 \\
\hline
\end{tabular}

Note: $\mathrm{FCD}=$ Fermented coconut dregs; $\mathrm{AS}=$ Ammonium sulfate; $\mathrm{UD}=$ undetected

Table 4. Growth performance of birds fed the experimental diets

\begin{tabular}{|c|c|c|c|c|c|}
\hline \multirow{2}{*}{ Variables } & \multirow{2}{*}{ Fermentation } & \multicolumn{3}{|c|}{ Levels of ammonium sulfate (\%) } & \multirow{2}{*}{ Average $e^{* *}$} \\
\hline & & 0 & 0.2 & 0.4 & \\
\hline \multirow[t]{2}{*}{ Body weight gain (g) } & 5 days & $1953 \pm 21.6$ & $2019 \pm 67.7$ & $1913 \pm 35.1$ & $1962 \pm 61.8^{a}$ \\
\hline & 7 days & $1898 \pm 8.26$ & $1974 \pm 24.8$ & $1900 \pm 58.0$ & $1924 \pm 49.6^{b}$ \\
\hline Average* $^{*}$ & & $1925 \pm 33.2^{\mathrm{b}}$ & $1997 \pm 53.1^{\mathrm{a}}$ & $1906 \pm 44.9^{b}$ & \\
\hline \multirow[t]{2}{*}{ Feed Intake (g) } & 5 days & $3499 \pm 212$ & $3389 \pm 571$ & $3407 \pm 77$ & $3431 \pm 324$ \\
\hline & 7 days & $3582 \pm 127$ & $3198 \pm 510$ & $3453 \pm 187$ & $3411 \pm 335$ \\
\hline Average* $^{*}$ & & $3540 \pm 168$ & $3293 \pm 511$ & $3430 \pm 135$ & \\
\hline \multirow[t]{2}{*}{ FCR } & 5 days & $1.79 \pm 0.12$ & $1.67 \pm 0.24$ & $1.78 \pm 0.05$ & $1.75 \pm 0.15$ \\
\hline & 7 days & $1.89 \pm 0.06$ & $1.62 \pm 0.25$ & $1.82 \pm 0.07$ & $1.78 \pm 0.18$ \\
\hline Average* & & $1.84 \pm 0.10^{\mathrm{a}}$ & $1.65 \pm 0.23^{b}$ & $1.80 \pm 0.06^{\mathrm{a}}$ & \\
\hline \multirow[t]{2}{*}{ Carcass (\%) } & 5 days & $66.2 \pm 3.67$ & $65.4 \pm 6.67$ & $69.5 \pm 2.64$ & $67.0 \pm 4.61$ \\
\hline & 7 days & $70.4 \pm 0.81$ & $65.7 \pm 5.10$ & $69.2 \pm 4.39$ & $68.4 \pm 6.33$ \\
\hline Average $^{*}$ & & $68.3 \pm 3.37$ & $65.5 \pm 8.15$ & $69.4 \pm 3.36$ & \\
\hline \multirow[t]{2}{*}{ Breast (\%) } & 5 days & $21.0 \pm 1.63$ & $20.2 \pm 1.26$ & $22.5 \pm 3.06$ & $21,2 \pm 2.17$ \\
\hline & 7 days & $21.9 \pm 1.79$ & $25.2 \pm 4.49$ & $22.3 \pm 1.71$ & $23.1 \pm 6.32$ \\
\hline Average* $^{*}$ & & $21.4 \pm 1.66$ & $22.9 \pm 8.02$ & $22.4 \pm 2.30$ & \\
\hline \multirow[t]{2}{*}{ Abdominal fat (\%) } & 5 days & $2.26 \pm 0.46$ & $1.64 \pm 0.91$ & $1.88 \pm 0.41$ & $1.93 \pm 0.63$ \\
\hline & 7 days & $1.00 \pm 0.19$ & $2.09 \pm 0.47$ & $1.75 \pm 0.41$ & $2.05 \pm 0.42$ \\
\hline Average $^{*}$ & & $2.29 \pm 0.32$ & $1.87 \pm 0.71$ & $1.81 \pm 0.39$ & \\
\hline
\end{tabular}

Note: ${ }^{*}=$ Means in the same row with different superscripts differ significantly $(\mathrm{p}<0.05) ; * *=$ Means in the same column and in the same variable with different superscripts differ significantly $(\mathrm{p}<0.05)$. 
Table 5. Feed digestibility and digestive organs of broilers fed the experimental diets

\begin{tabular}{|c|c|c|c|c|c|}
\hline \multirow{2}{*}{ Variables } & \multirow{2}{*}{ Fermentation } & \multicolumn{3}{|c|}{ Levels of ammonium sulfate (\%) } & \multirow{2}{*}{ Average ${ }^{* *}$} \\
\hline & & 0 & 0.2 & 0.4 & \\
\hline \multirow[t]{2}{*}{ DMD (\%) } & 5 days & $80.3 \pm 0.36$ & $83.5 \pm 0.81$ & $82.9 \pm 0.52$ & $82.2 \pm 1.55$ \\
\hline & 7 days & $80.2 \pm 1.71$ & $82.3 \pm 0.74$ & $81.8 \pm 2.04$ & $81.5 \pm 1.71$ \\
\hline Average & & $80.3 \pm 1.14^{\mathrm{b}}$ & $82.9 \pm 0.97^{a}$ & $82.4 \pm 1.49^{a}$ & \\
\hline \multirow[t]{2}{*}{ Protein digestibility (\%) } & 5 days & $84.0 \pm 0.82$ & $86.2 \pm 1.20$ & $86.2 \pm 1.11$ & $85.5 \pm 1.44$ \\
\hline & 7 days & $83.2 \pm 0.39$ & $85.3 \pm 0.85$ & $84.1 \pm 3.01$ & $84.2 \pm 1.86$ \\
\hline Average* & & $83.6 \pm 0.72^{b}$ & $85.8 \pm 1.09^{a}$ & $85.1 \pm 2.37^{\mathrm{ab}}$ & \\
\hline \multirow[t]{2}{*}{ Gizzard (g/kg BW) } & 5 days & $1.64 \pm 0.18$ & $1.59 \pm 0.17$ & $1.62 \pm 0.14$ & $1.62 \pm 0.15$ \\
\hline & 7 days & $1.60 \pm 0.06$ & $1.73 \pm 0.11$ & $1.69 \pm 0.09$ & $1.67 \pm 0.09$ \\
\hline Average* & & $1.62 \pm 0.13$ & $1.66 \pm 0.15$ & $1.65 \pm 0.11$ & \\
\hline \multirow[t]{2}{*}{ Duodenum $(\mathrm{cm} / \mathrm{kg}$ BW) } & 5 days & $9.4 \pm 1.41$ & $8.2 \pm 1.18$ & $9.5 \pm 1.61$ & $9.0 \pm 1.42$ \\
\hline & 7 days & $8.2 \pm 0.99$ & $9.5 \pm 0.50$ & $9.7 \pm 1.64$ & $9.1 \pm 1.24$ \\
\hline Average* & & $8.8 \pm 1.30$ & $8.8 \pm 1.09$ & $9.6 \pm 1.51$ & \\
\hline \multirow[t]{2}{*}{ Jejunum (cm/kg BW) } & 5 days & $33.9 \pm 3.14$ & $30.6 \pm 2.04$ & $35.4 \pm 1.83$ & $33.3 \pm 3.00$ \\
\hline & 7 days & $33.1 \pm 2.88$ & $38.4 \pm 10.1$ & $37.1 \pm 4.03$ & $36.2 \pm 6.50$ \\
\hline Average $^{*}$ & & $33.5 \pm 2.82$ & $34.5 \pm 7.91$ & $36.2 \pm 3.56$ & \\
\hline \multirow[t]{2}{*}{ Ileum (cm/kg BW) } & 5 days & $30.9 \pm 4.00$ & $28.7 \pm 2.73$ & $32.2 \pm 1.33$ & $30.6 \pm 3.01$ \\
\hline & 7 days & $28.5 \pm 1.45$ & $33.9 \pm 6.82$ & $36.3 \pm 7.94$ & $32.9 \pm 6.49$ \\
\hline Average* & & $29.7 \pm 3.08$ & $31.4 \pm 5.57$ & $34.2 \pm 5.71$ & \\
\hline
\end{tabular}

Note: $\mathrm{DMD}=$ Dry matter digestibility; $\mathrm{BW}=$ Body weight; ${ }^{*}=$ Means in the same row with different superscripts differ significantly $(\mathrm{p}<0.05) ;{ }^{*}=\mathrm{Means}$ in the same column with different superscripts differ significantly $(\mathrm{p}<0.05)$.

Organ dimensions (relative weight and length) were not affected by the addition of ammonium sulfate. There was no interaction between the duration of fermentation and the levels of ammonium sulfate on the digestibility of dry matter and protein, gizzard weight, and intestinal length.

\section{DISCUSSION}

\section{Nutrient Profiles and Physical Properties of Fermented Coconut Dregs}

It is expected that fermentation could lower the lipid content of the CD. This might indicate that the yeast Saccharomyces cerevisiae utilized the fat content of CD for a source of nutrients. The decreased fat concentration in CD due to fermentation was also reported by Mozin et al. (2019), who found that the fat content of rice bran decreased when it was fermented either by Saccharomyces cerevisiae or Aspergillus niger. The addition of ammonium sulfate into the CD prior to fermentation either at the level of 0.2 or $0.4 \%$ could further decrease the fat content of CD.

The crude fiber content of CD was relatively high, being $34 \%$. The high concentration of crude fiber was dependent upon the contamination of a nutshell of coconut since the content of a nutshell was mainly lignin (Sundu et al., 2009). According to Mozin et al. (2019), fermentation could decrease the fibrous fraction of the substrate. During fermentation of the CD, mannanase enzyme was produced to break down the fiber into simpler carbohydrates (Bahri et al., 2019) and thus decreased the concentration of crude fiber in the CD. Since dietary fiber was bio-converted into a simple frac- tion, the substrate becomes heavier, as was indicated by a high bulk density. This current finding indicated that bulk density increased due to the fermentation process. Since fiber had the capacity to bind water (Ngoc et al., 2012), reducing the fiber content of the substrate could lower the capacity of the substrate to bind more water. This logic assumption was supported by these current findings that fermentation decreased water holding capacity from 5.75 to between 4.13 and $5.08 \mathrm{~g}$ water/g substrate.

Although there was an increase in protein content due to fermentation, the addition of ammonium sulfate into the CD prior to fermentation could further increase the protein content of the substrate, particularly in CD supplemented with $0.2 \%$ ammonium sulfate fermented for 7 days and CD supplemented with $0.4 \%$ ammonium sulfate fermented for 5 days (Table 3). The same pattern was found in the concentrations of amino acids in which CD supplemented with $0.2 \%$ ammonium sulfate fermented for 7 days and CD supplemented with $0.4 \%$ ammonium sulfate fermented for 5 days had a higher number of amino acids. Unexpectedly, the addition of more ammonium sulfate $(0.4 \%)$ in the CD prior to fermentation could not produce higher concentrations of protein and amino acids. It can be stated here that the ideal concentration of ammonium sulfate supplementation to increase amino acids concentration was $0.2 \%$. It is possible that the higher number of nitrogen in the CD supplemented with $0.4 \%$ ammonium sulfate fermented for 5 and 7 days were converted into ammonia and released to the air.

Amino acids containing sulfur (cysteine and methionine) present in $\mathrm{CD}$ were undetectable that was below $12 \mathrm{mg} / \mathrm{kg}$ for methionine and $161 \mathrm{mg} / \mathrm{kg}$ for cys- 
teine. Fermenting the $\mathrm{CD}$ without ammonium sulfate supplementation still produced undetected methionine and cysteine. The addition of ammonium sulfate at the levels of 0.2 and $0.4 \%$ could increase the number of amino acids containing sulfur. Interestingly, the duration of fermentation could differently produce amino acids containing sulfur where cysteine was produced when the CD supplemented with ammonium sulfate was fermented for 5 days. Fermenting the substrate for 7 days produced a higher number of methionine as amino acid containing sulfur. These findings indicated that sulfur present in the ammonium sulfate was bio converted into an organic form of amino acids containing sulfur (methionine or cysteine) since sulfurs in methionine or cysteine amino acids might be originated from sulfur in ammonium sulfate supplemented in the CD.

\section{Growth Performance, Abdominal Fat, and Carcass Percentage}

Supplementation of diets with fermented substrate could produce heavier birds (Yasar et al., 2016). This result is related to the role of fermentation that could improve the feeding value of diets through the production of an enzyme (Kapilan, 2015). Since the duration of fermentation could affect the production of enzymes, the quality of the substrate relied on the duration of fermentation. It was clear that fermentation of CD for 5 days produced a better quality of the substrate since birds fed ration supplemented with fermented $\mathrm{CD}$ for 5 days had higher body weights. However, the mechanism of increased performance of birds fed ration supplemented with fermented CD was unclear since the digestibility of the diets was not affected by the duration of fermentation. It can be speculated that birds fed ration supplemented with CD fermented for 7 days could utilize more nutrients than birds fed ration supplemented with $\mathrm{CD}$ fermented for 5 days that converted the nutrients into waste products such as $\mathrm{CO}_{2}$ and heat. Feed intake, FCR, abdominal fat, carcass, and breast percentages of experimental birds were not affected by the duration of fermentation.

Feeding the experimental birds with a diet containing $0.2 \%$ ammonium sulfate and fermented CD increased the bodyweight gain of birds by about $3.7 \%$. This increase in body weight gain of birds might be related to the increase in dry matter and protein digestibility (Table 5), coupled with the increase in protein and amino acid concentrations. However, when the concentration of ammonium sulfate was increased to $0.4 \%$ included in the CD before fermentation, the body weight gain of birds fed the $0.4 \%$ ammonium sulfate diet was not improved compared to the birds fed the fermented $\mathrm{CD}$ that was not supplemented with ammonium sulfate. This result is an anomaly since the dry matter digestibility of the ration increased. The possible reason might be that the inclusion of $0.4 \%$ ammonium sulfate could not enhance protein digestibility. It is possible that the addition of $0.4 \%$ ammonium sulfate in the substrate was too much in the sense of improving feeding value and thus could not be recommended in the fermentation process when $C D$ was used as substrates.

Since the experimental birds fed ration supplemented with $0.2 \%$ ammonium sulfate in the substrate were heavier while the birds consumed the same amount of feed as others, FCR of the diet was better. However, this bodyweight difference could not produce a higher percentage of carcass. Breast and abdominal fat of birds were also unaffected by the treatments.

\section{Digestibility of Dry Matter, Protein, and Digestive Organs Dimensions}

The effect of diets containing a fermented CD with the addition of ammonium sulfate on feed digestibility has not been reported in the database. The current findings indicated that dry matter digestibility of the diet was increased as a result of the addition of ammonium sulfate before fermentation. Ammonium sulfate might play a role in increasing the growth of the yeast. Schmidt \& Furlong (2012) found that the addition of ammonium sulfate in the medium could increase biomass production of fermented rice bran. The increase in the population and proliferation of Saccharomyces cerevisiae might improve the production of enzymes to hydrolyze and utilize the fiber fraction of CD for the maintenance of the yeasts. Bahri et al. (2019) found that when coconut waste product was fermented, a mannanase enzyme was produced. Early study of Hatta et al. (2014) also indicated the production of cellulase enzyme when copra or coconut meal was fermented using Trichoderma viride. These two enzymes are responsible for the degradation of cellulose and non-starch polysaccharides rich in mannose that are the main components of dietary fiber in coconut meal (Ngoc et al., 2012; Sundu et al., 2012). Once the digestibility of the dietary fiber of CD increased, the overall digestibility of dry matter was improved.

It has been well accepted that the addition of nitrogen in the medium could increase the production of protein (Akintomide \& Antai, 2012). The supplementation of white yam peels as a substrate with ammonium sulfate before fermentation with Saccharomyces cerevisiae increased protein yield (Akintomide \& Antai, 2012). Since solid-state fermentation aimed at producing enzymes, the enzymes produced were dependent upon the concentration of nutrients (Kapilan, 2015). Using coconut in the present study with a high concentration of lipid and the addition of ammonium sulfate, as a medium of fermentation with Saccharomyces cerevisiae might produce protease and lipase enzymes. Masyithah (2017) used coconut milk and fermented with Saccharomyces cerevisiae in her study found that lipase and protease enzymes were produced to break down molecules to produce coconut oil. The production of protease during fermentation and the addition of ammonium sulfate might generate more protease and thus increased protein digestibility in the current study.

Digestive organ dimensions, either gizzard and small intestine relative weights were not affected by the duration of fermentation and levels of ammonium 
sulfate. According to Sundu et al. (2009), digestive organ dimensions were partly caused by the dietary fiber of the diet, along with the live body weight of birds. The enlarged gizzards of birds fed copra meal-based diets were a response to accommodate more fibrous digests passing through the gizzard. Accordingly, the addition of only $1 \%$ fermented CD could not affect much the crude fiber concentration of the current diets. It thus could not produce any significant difference in the digestive organs dimension.

\section{CONCLUSION}

Fermentation at both 5 days and 7 days decreased lipid and the crude fiber content of coconut dregs. The addition of ammonium sulfate in the medium of coconut dregs increased protein and amino acids concentration. Moreover, the bodyweight gain, feed conversion ratio, dry matter digestibility, and protein digestibility improved due to ammonium sulfate addition in the coconut dregs before fermentation.

\section{CONFLICT OF INTEREST}

Burhanudin Sundu serves as an editor of the Tropical Animal Science Journal, but has no role in the decision to publish this article. The authors assure that this article has no conflict of interest with the funding body and any producers or institutions mentioned in this article.

\section{ACKNOWLEDGEMENT}

The authors would like to express our sincere thanks to the Ministry of Research, Technology and Higher Education through the Universitas Tadulako for providing the financial supports, enabling us to do this research. We would also like to thank the Faculty of Animal Husbandry and Fisheries for the research facilities used in this study. Our gratitude also goes to the students involved in this study for their supports in taking care of the birds and cleaning up the pens.

\section{REFERENCES}

Abhiney, J., M. Charles, \& J. Henson. 2012. Comparison of solid-state and submerged-state fermentation for the bioprocessing of switchgrass to ethanol and acetate by Clostridium phytofermentants. Appl. Microbiol. Biotechnol., 97: 905-917. https://doi.org/10.1007/s00253-012-4511-4

Akintomide, M. J. \& S. P. Antai. 2012. Inorganic nitrogen supplementation and mico-fungal fermentation of white yam peels (flour) into single cell protein. J. Microbiol. Biotech. Food Sci. 2: 820-832.

AOAC. 1990. Official Methods of Analysis of AOAC. $3^{\text {rd }}$ Ed. Association of Official Analytical Chemist, Washington DC.

Bahri, S., B. Sundu, \& M. R. Aprianto. 2019. Mannanase activity produced through fermentation of coconut flour at various $\mathrm{pH}$ by Aspergilus niger. Journal of Physics: Conference Series 1242 (1), 012009. https://doi. org/10.1088/1742-6596/1242/1/012009

FAO (Food and Agriculture Organization). 2017. Coconut
Production. http.fao.org/faostat/en/\#data/qc. [3 August 2019].

Hatta, U., O. Sjofjan, I. Subagiyo, \& B. Sundu. 2014. Effects of fermentation on nutritive value of copra meal, cellulase activity and performance of broiler chickens. Livest. Res. Rural Dev. 26: 61.

Jacob, N. \& P. Prema. 2006. Influence of mode of fermentation on production of polygalaturonase by a novel strain of streptomyces lydicus. Food Technol. Biotechnol. 44: 263-267

Jensen, J. F. 1984. Method of Dissection of Broiler Meat Carcasses and Description of Parts. First edition. Papworth's Pendagron Press, Cambridge, UK, .

Kapilan, R. 2015. Solid state fermentation for microbial products: A review. Arch. Appl. Sci. Res. 7: 21-25

Kong, C. \& O. Adeola. 2014. Evaluation of amino acids and energy utilization in feedstuffs for swine and poultry diets. Asian- Australas. J. Anim. Sci. 27: 917-925. https://doi. org/10.5713/ajas.2014.r.02

Kumar, A. \& S. S. Kanwar. 2012. Lipase production in solidstate fermentation (SSF): recent developments and biotechnological applications. Dyn Biochem, Process Biotechnol. Mol. Biol. 6:13-27.

Kyriazakis, I. \& G. C. Emmans. 1995. The voluntary feed intake of pigs given feed based on wheat bran, dried citrus pulp and grass meal, in relation to measurements of feed bulk. Brit. J. Nutr. 73: 191-207. https://doi.org/10.1079/ BJN19950023

Masyithah, Z. 2017. Parametric study in production of virgin coconut oil by fermentation method. Oriental J. Chem. 33 3069-3076. https://doi.org/10.13005/ojc/330647

Mozin, S., U. Hatta, S. Sarjuni, M. Gobel, \& B. Sundu. 2019. Growth performance, feed digestibility and meat selenium of broilers fed fungi-fermented rice bran with addition of inorganic selenium. Int. J. Poult. Sci. 18: 438-444. https:// doi.org/10.3923/ijps.2019.438.444

Ngoc, T. T. B., N. T. Len, \& J. E. Linberg. 2012. Chemical charceterization and water holding capacity of fibre-rich feedstuffs used for pigs in Vietnam. Asian- Aust. J. Anim. Sci., 25: 861-868. https://doi.org/10.5713/ajas.2011.11294

Nissen. P., D. Nielsen, \& N. Arnborg. 2003. Viable Saccharomyces cerevisiae cells at high concentrations cause early growth arest of non-Saccharomyces yeast in mixed cultures by a cell-cel contact-mediated mechanism. Yeast. 20: 331-341. https://doi.org/10.1002/yea.965

Nyamete, F. A., B. Mourice, \& J. K. Mugula. 2016. Fumonisin B1 in lactic acid bacteria fermentation of maize porridges. Tanzania J. Agric. Sci. 15: 13-20.

NRC. 1994. Nutrient Requirements of Poultry. National Academy Press, Washington DC.

Saunshia, Y., M.V.S. Sandhya, J. M. R. Lingamallu, J. Padella, \& M. Pushpa. 2018. Improved fermentation of cocoa beans with enhanced aroma profiles. Food Biotechnol, 32: 257272. https://doi.org/10.1080/08905436.2018.1519444

Schmidt, C. G. \& E. B. Furlong. 2012. Effect of particle size and ammonium sulfate concentration on rice bran fermentation with the fungus Rhizopus orizae. Bioresource Technol. 123: 36-41. https://doi.org/10.1016/j.biortech.2012.07.081

Seltman, H. J. 2018. Experimental design and Analysis. Carnegie Mellon University, Pittsburgh, USA.

Sugiharto, S. \& S. Ranjitkar. 2019. Recent advance in fermented feeds towards improved broiler chicken performance, gastrointestinal tract microecology and immune responses: A review. Anim. Nutr. 5: 1-10. https://doi.org/10.1016/j. aninu.2018.11.001

Sukaryana, Y., U. Atmomarsono, V. D. Yunianto, \& E. Supriyatna. 2010. Bioconversions of palm kernel cake and rice bran mixtures by Trichoderma viride toward nutritional contents. Int. J. Sci. Eng. 1: 27 - 32. 
Sundu, B., A. Kumar, \& J. Dingle. 2008. Amino acids digestibility of palm kernel meal in poultry. J. Indonesian Trop. Anim. Agric. 33: 139-144.

Sundu, B., A. Kumar, \& J. Dingle. 2009. Feeding Value of copra meal for Broilers. World's Poult. Sci. J. 65: 481-492. https:// doi.org/10.1017/S0043933909000348

Sundu, B., U. Hatta, \& A. S. Chaudhry. 2012. Potential use of beta mannan from copra meal as a feed additive for broilers. World's Poult. Sci. J. 68: 707-716. https://doi. org/10.1017/S0043933912000839
Sundu, B., U. Hatta, S. Mozin, \& A. Adjis. 2019. The effect of fermented coconut dregs with the addition of inorganic selenium on feed digestibility, growth performance and carcass traits of broiler chickens. Livest. Res. Rural Dev. 31: 11 .

Yasar, S., M. S. Gok, \& Y. Gurbuz. 2016. Performance of broilers fed raw or fermented and redried wheat, barley and oat grains. Turkish J. Vet. Anim. Sci. 40: 313-322. https://doi. org/10.3906/vet-1505-44 